\title{
Location of the Catalytic Site of the Respiratory Fumarate Reductase of Escherichia coli
}

\author{
By D. SIMPKIN AND W. J. INGLEDE W* \\ Department of Biochemistry and Microbiology, Unitersity of St Andrews. \\ St Andrew's KYI6 9AL, UK
}

(Received 9 March 1984; revised 30 May 1984)

\begin{abstract}
The location of the catalytic site of the membrane-bound respiratory fumarate reductase of Escherichia coli was investigated using mutants and inhibitors of dicarboxylic acid transport. Comparison of apparent $K_{\mathrm{m}}$ and $V_{\max }$ values for fumarate in intact cells and in inverted membrane vesicles showed that externally added fumarate was required to be transported across the cytoplasmic membrane prior to reduction. The catalytic site of fumarate reductase must therefore be located on the cytoplasmic face of the membrane.
\end{abstract}

\section{INTRODUCTION}

Escherichia coli grows anaerobically on several non-fermentable substrates when fumarate is provided as an electron acceptor. The respiratory chain developed under these growth conditions is terminated by a membrane-bound fumarate reductase (EC 1.3.99.1). It is important to determine whether fumarate is reduced in the cytoplasm or in the periplasm, so that the inter-relationship between the organization of the respiratory chain and its protontranslocating ability can be understood.

Direct evidence that the fumarate reductase enzyme complex is at least in part located on the cytoplasmic side of the membrane has been presented by a number of workers using immunological and electron microscopic methods (Van der Plas et al., 1983; Lemire et al., 1983). However, the location of the catalytic site of a membrane-bound enzyme need not be the same as that of the bulk of the enzyme protein as detected by non-enzymic means. In this paper, fumarate reduction by intact cells and membrane particles has been measured in dicarboxylic acid transport mutants and with inhibitors of dicarboxylic acid transport present, in order to determine the location of the catalytic site.

\section{METHODS}

Growth of organisms. The organisms used in this study are listed in Table 1. Bacteria were grown anaerobically at $37^{\circ} \mathrm{C}$ in $500 \mathrm{ml}$ bottles filled to the neck with either the glycerol/fumarate medium of Spencer \& Guest (1973) or with nutrient broth containing glucose $(0.5 \%, w / v)$. Bacteria were harvested by centrifugation $(8500 \mathrm{~g}, 15 \mathrm{~min})$ after $18 \mathrm{~h}$, washed twice in potassium phosphate buffer $(50 \mathrm{mM}, \mathrm{pH} 7.5)$ and resuspended in the same buffer.

Preparation of membrane particles. Inverted membrane particles were prepared by French pressure cell treatment as described by Reid \& Ingledew (1979).

Enzyme assays. Rates of $\mathrm{O}_{2}$ consumption were measured at $30^{\circ} \mathrm{C}$ in a Clark-type $\mathrm{O}_{2}$ electrode. The buffer used was potassium phosphate ( $50 \mathrm{mM}, \mathrm{pH} 7.5$ ), all substrates were $5 \mathrm{~mm}$ (final concentration) and the cells or membrane particles were approximately $0.25 \mathrm{mg}$ protein $\mathrm{ml}^{-1}$ (final concentration in a $3 \mathrm{ml}$ reaction volume).

Fumarate reductase activity was measured spectrophotometrically at $30^{\circ} \mathrm{C}$ by following the rate of oxidation of reduced benzyl viologen, using the method of Spencer \& Guest (1973) modified as follows. Benzyl viologen $(120 \mu \mathrm{m})$ was reduced by titration with a freshly prepared saturated solution of sodium dithionite, to give an absorbance at $550 \mathrm{~nm}$ of 0.8 to 0.9 . Fumarate and $C_{4}$-dicarboxylic acids were then added and the rate of basal oxidation was followed for $5 \mathrm{~min}$ before the reaction was initiated by the addition of cells or membrane particles $(0 \cdot 25 \mathrm{mg}$ protein $\mathrm{ml}^{-1}$ and $7.0 \mu \mathrm{g}$ protein $\mathrm{ml}^{-1}$, respectively). The buffer used was potassium phosphate $(50 \mathrm{~mm}, \mathrm{pH} 7.5)$ 
Table 1. Strains of E. coli KI2 used in this study

\begin{tabular}{|c|c|c|}
\hline Strain & Characteristic * & Origin \\
\hline $\begin{array}{l}\text { EMG2 } \\
\text { JRG1031 } \\
\text { CBT38 } \\
\text { CBT312 } \\
\text { CBT313 }\end{array}$ & $\begin{array}{l}\text { Prototroph } \\
\text { Amplified frd } \\
\left.\begin{array}{l}d c t B 3 \\
\operatorname{dct} A 2 \\
d c t A 4\end{array}\right\}\end{array}$ & $\begin{array}{l}\text { M. Peacey, University of Edinburgh, UK } \\
\text { J. R. Guest, University of Sheffeld, UK } \\
\text { E. coli Genetic Stock Center, Yale University, } \\
\text { School of Medicine, New Haven. } \\
\text { Conn. } 06510 \text {, USA }\end{array}$ \\
\hline
\end{tabular}

- Genotype designations: frd, fumarate reductase; $d c t$, dicarboxylic acid transport.

which was de-oxygenated by bubbling with $\mathrm{O}_{2}$-free $\mathrm{N}_{2}$. Apparent values of $K_{\mathrm{m}}$ and $V_{\max }$ were determined graphically from Lineweaver-Burk plots (Table 3 ) and checked by replotting on Eadie-Hofstee plots. Similar results were obtained from both methods.

Protein was measured by the Lowry method, with the inclusion of $1 \%(w / v)$ SDS to ensure solubility of membrane proteins.

\section{RESULTS}

Fumarate reductase activities of intact cells and membrane particles of $E$. coli were compared in order to determine any requirement for a transport process for fumarate. Two experimental approaches were used. Firstly, fumarate reductase activities in a number of strains, some of which lacked the dicarboxylic acid carrier (dct mutants) were compared; and secondly, fumarate reductase activities in the presence of inhibitors of the dicarboxylic acid carrier were measured. Fumarate reductase activity was assayed by measuring the oxidation of reduced benzyl viologen. Jones \& Garland (1977) have shown that reduced benzyl viologen can readily cross the cytoplasmic membrane of $E$. coli $\mathrm{K} 12$.

\section{Studies with dct mutants}

Fumarate reductase activities in intact bacteria and membrane particles derived from dct mutant strains were compared with those of the wild-type. The dct mutants could not grow by fumarate respiration, so all strains were grown on nutrient broth for these experiments. This mode of growth had the disadvantage of yielding lower activities for both the fumarate reductase and (where present) the dicarboxylic acid carrier. Substantial rates of fumarate reductase activity were detected in the intact cells of strains EMG2 and JRG1031, but there was no activity observed in the mutants CBT38, CBT312 and CBT313 (Table 2). The membrane particles of all strains had fumarate reductase activity. The fumarate reductase activity was greatest in the strain containing amplification of the frd gene (JRG1031). Comparison of the rates of fumarate reduction by cells and membrane particles showed that fumarate reductase activity was masked in intact cells of all strains except EMG2 (Table 2). NADH oxidase activities were also measured with the membrane preparations to give an indication of membrane integrity. A functional electron transport chain was shown in all preparations. NADH oxidase was not measured with whole cells. The apparent relationship between the NADH oxidase and fumarate reductase activities may be due to NADH dehydrogenase acting as an electron donor to the electron transport chain when fumarate reductase is the major site of terminal electron transfer. In strain JRG1031, the rate of fumarate reduction in whole cells was high, but the specific activity in the membranes was tenfold greater, presumably because a rate limitation imposed by the transport process was removed in the latter case. In the dct mutants no activity was observed in intact cells, presumably because the fumarate could not enter. These observations show the requirement for a dicarboxylic acid carrier in whole celis but not in particles, indicating that the site of fumarate reduction is cytoplasmic.

\section{Fumarate reductase activities in the presence and absence of inhibitors}

$E$. coli strains EMG2 and JRG1031 were grown in glycerol/fumarate medium, which enables growth by fumarate respiration and induces high activities of fumarate reductase (Spencer \& Guest, 1973). Maximum rates $\left(V_{\text {max }}\right)$ and $K_{m}$ values were determined graphically (Table 3$)$ as de- 
Table 2. Fumarate reductase activities of whole cells and membrane particles from frd and dct mutants of $E$. coli $K 12$

All strains of $E$. coli were grown in nutrient broth because dct mutants did not grow in glycerol/fumarate medium. Inverted membrane vesicles were prepared using a French pressure cell. Fumarate reductase activities are given in nmol fumarate reduced (mg protein) ${ }^{-1} \mathrm{~min}^{-1}$ (from the rate of oxidation of benzyl viologen). The results are the mean values ( \pm the maximum deviation from the mean) of three assays on each of three separate cultures. NADH oxjdase activities are expressed in $\mathrm{nmol} \mathrm{O}_{2}$ ( $\mathrm{mg}$ protein) ${ }^{-1} \mathrm{~min}^{-1}$.

Whole cells

Strain

EMG2

JRG1031

CBT38

CBT312

CBT313
Fumarate reductase

$65 \pm 4$
$80 \pm 7$
0
0
0

Membrane particles

$\begin{array}{cr}\text { Fumarate reductase } & \text { NADH oxidasc } \\ 125 \pm 11 & 30 \pm 2 \\ 910 \pm 20 & 83 \pm 5 \\ 20 \pm 3 & 6 \pm 1 \\ 40 \pm 6 & 5 \pm 1 \\ 50 \pm 6 & 5 \pm 1\end{array}$

Table 3. Fumarate reductase activities in the presence of added dicarboxylic acids

Bacteria were grown on glycerol/fumarate medium. $K_{m}$ and $V_{\max }$ values are the mean values $( \pm$ the maximum deviation from the mean) of three separate determinations obtained from plots of rate data at eight substrate concentrations. Disodium salts of the DL-dicarboxylic acids were added ( $5 \mathrm{mM}$ ) as inhibitors. $V_{\max }$ values are expressed as $\mu \mathrm{mol}$ fumarate reduced ( $\mathrm{mg}_{\mathrm{g}}$ protein) ${ }^{-1} \mathrm{~min}^{-1}$, as explained in Table 2.

\begin{tabular}{|c|c|c|c|c|c|}
\hline \multirow[b]{2}{*}{ Strain } & \multirow[b]{2}{*}{$\begin{array}{c}\text { Inhibitor } \\
\text { added }\end{array}$} & \multicolumn{2}{|c|}{$K_{m}(\mathbf{m u})$} & \multicolumn{2}{|c|}{$\underbrace{V_{\text {max }}}_{\max }$} \\
\hline & & $\begin{array}{l}\text { Whole } \\
\text { cells }\end{array}$ & $\begin{array}{c}\text { Membrane } \\
\text { particles }\end{array}$ & $\begin{array}{l}\text { Whole } \\
\text { cells }\end{array}$ & $\begin{array}{c}\text { Membrane } \\
\text { particles }\end{array}$ \\
\hline $\begin{array}{l}\text { EMG2 } \\
\text { EMG2 } \\
\text { EMG2 } \\
\text { EMG2 } \\
\text { JRG1031 } \\
\text { JRG1031 } \\
\text { JRG1031 } \\
\text { JRG1031 }\end{array}$ & $\begin{array}{l}\text { None } \\
\text { Aspartate } \\
\text { Malate } \\
\text { Tartrate } \\
\text { None } \\
\text { Aspartate } \\
\text { Malate } \\
\text { Tartrate }\end{array}$ & $\begin{array}{c}0.25 \pm 0.03 \\
0.79 \pm 0.04 \\
(0.71 \pm 0.07) \\
0.30 \pm 0.07 \\
0.78 \pm 0.03 \\
2.73 \pm 0.09 \\
(3.00 \pm 0.08) \\
0.79 \pm 0.04\end{array}$ & $\begin{array}{l}0.20 \pm 0.07 \\
0.23 \pm 0.07 \\
0.86 \pm 0.05 \\
0.67 \pm 0.09 \\
0.25 \pm 0.07 \\
0.25 \pm 0.08 \\
0.71 \pm 0.1 \\
2.22 \pm 0.2\end{array}$ & $\begin{array}{c}1.57 \pm 0.1 \\
1.58 \pm 0.09 \\
(1.60 \pm 0.11) \\
1.55 \pm 0.07 \\
12.0 \pm 0.9 \\
11.3 \pm 0.5 \\
(12.1 \pm 0.7) \\
11.9 \pm 0.9\end{array}$ & $\begin{array}{l}1.62 \pm 0.4 \\
1.57 \pm 0.3 \\
1.65 \pm 0.7 \\
1.55 \pm 0.4 \\
12.5 \pm 0.8 \\
12.6 \pm 0.8 \\
12.5 \pm 0.7 \\
12.4 \pm 0.4\end{array}$ \\
\hline
\end{tabular}

scribed in Methods. In the glycerol/fumarate-grown strain EMG2 there was no significant difference between these values in cells and membrane particles in the absence of an inhibitor. In strain JRG1031, a $K_{\mathrm{m}}$ value of $0.25 \mathrm{mM}$ for fumarate was observed in the membrane preparation, close to that obtained in EMG2, but a $K_{\mathrm{m}}$ value of $0.78 \mathrm{mM}$ was observed for whole cells. Presumably the $K_{\mathrm{m}}$ of $0.25 \mathrm{mM}$ was a consequence of rate limitation of fumarate reductase itself, so in EMG2 cells and membranes and in JRG1031 membranes the reductase step was rate-limiting. In strain JRG1031, the fumarate reductase is amplified and appeared to cause the porter for fumarate entry to become rate-limiting in whole cells. Thus the $K_{\mathrm{m}}$ of $0.78 \mathrm{mM}$ reflects the affinity of the dicarboxylic acid carrier, rather than the fumarate reductase, for fumarate.

The use of aspartate, malate and tartrate as inhibitors of either the dicarboxylic acid carrier or fumarate reductase confirmed the need for a dicarboxylic acid carrier for fumarate reduction in intact cells (Table 3). Aspartate did not inhibit fumarate reduction by membrane particles, but it was effective as a competitive inhibitor in whole cells. Our interpretation of these results is that aspartate is an inhibitor of the transport process (Kay \& Kornberg, 1971) but not of fumarate reductase, and hence is an inhibitor of fumarate reduction only in intact cells. Tartrate had only a marginal effect on fumarate reductase activity in whole cells, but was a competitive inhibitor of fumarate reductase activity in membrane particles. Malate inhibited in both cells and membrane preparations. In control experiments, no detectable oxidase activities were observed for aspartate, malate and tartrate in membrane preparations or cells (using an $\mathrm{O}_{2}$ electrode). Only 
malate supported benzyl viologen oxidation, and then only in whole cells. The rates of malatesupported viologen oxidation were $78 \pm 6 \mathrm{nmol} \mathrm{min}^{-1}(\mathrm{mg} \text { protein) })^{-1}$ for strain JRG 1031 and $82 \pm 5 \mathrm{nmol} \mathrm{min}{ }^{-1}(\mathrm{mg} \text { protein) })^{-1}$ for strain EMG2, indicating the presence of fumarase activity in whole cells. This complicates the interpretation of the data obtained with whole cells in the presence of malate (values in parentheses in Table 3). However, the $K_{m}$ for fumarate was increased in the presence of malate, showing that the primary effect of malate on fumarate reduction in whole cells was to inhibit fumarate reduction at the level of the dicarboxylic acid porter. If the conversion of malate to fumarate had distorted the results (initial rates were measured) then, in the absence of any other effect, an apparent lowering of the $K_{m}$ for fumarate would result.

\section{DISCUSSION}

These studies, using dct mutants and inhibitors of the dicarboxylic acid carrier and fumarate reductase, show that in whole cells the transmembrane transport of fumarate must precede its reduction. Thus the catalytic site of the fumarate reductase must be located on the cytoplasmic aspect of the cytoplasmic membrane.

Van der Plas et al. (1983) used a crossed immuno-electrophoretic approach to analyse the membrane proteins of $E$. coli grown on glycerol with fumarate as respiratory oxidant and extended their analysis to immuno-absorption studies. By comparing the antibody binding to intact (right-side out) and disrupted membrane vesicles, they calculated the relative expression of the fumarate reductase antigen at the external and internal membrane surfaces. It was concluded that the antigenic determinants of $E$. coli fumarate reductase were located on the cytoplasmic aspect of the cytoplasmic membrane. The location of the catalytic site was not determined, however, and the absence of antigenic determinants from the periplasmic aspect of the membrane cannot be taken as conclusive proof of the absence of any part of the fumarate reductase from this side of the membrane.

Lemire et al. (1983) attempted to determine the structure of fumarate reductase in inverted membrane vesicles by a combination of antibody binding studies and electron microscopy. They identified 'knob-like' structures, observed on the cytoplasmic side of the cytoplasmic membrane, with the catalytic subunits of fumarate reductase, since removal of the fumarate reductase activity from the membrane preparation by chymotrypsin or urea treatment and restoration by incubation of the stripped membranes with a fumarate reductase preparation resulted in a corresponding loss and reappearance of the 'knobs'. This work indicated that the bulk of the fumarate reductase is membrane-associated and located on the cytoplasmic aspect of the membrane, and thus implied that the catalytic site is also cytoplasmic. However, the possibility that the major part of the enzyme is located cytoplasmically, yet the substrate site is still accessible from the periplasmic phase, could not be ruled out.

Jones \& Garland (1977) assumed a cytoplasmic location for fumarate reductase on the basis of the abilities of oxidation-reduction dyes to reduce fumarate in intact and broken cells, but this approach suffered from a lack of knowledge of the site of interaction between the dyes and the respiratory chain. Gutowski \& Rosenberg $(1976,1977)$ also argued for an internal location of the fumarate reductase catalytic site on the basis of the effect of tartrate on respiratory proton translocation supported by a pulse of fumarate. The conclusion that the quenching of the acidification was due to an inhibition of the transport process by tartrate can be questioned on two points. Firstly, tartrate is a better inhibitor of fumarate reductase than of the dicarboxylic acid carrier. Secondly, tartrate would be expected to quench the measured proton translocation by entering the cell in symport with a proton as soon as any $\Delta \mathrm{pH}$ is established, because the dicarboxylic acid carrier is a proton symporter (Gutowski \& Rosenberg, 1976).

In this paper we have presented evidence that the catalytic site of fumarate reductase is situated on the cytoplasmic aspect of the cytoplasmic membrane, by demonstrating a requirement for a functional dicarboxylic acid carrier to support both fumarate reduction in whole cells and growth with fumarate as terminal electron acceptor. This complements the findings of others which showed that the bulk of the enzyme protein was similarly located. 
We thank Professor J. R. Guest for the gift of Escherichia coli K 12 strain JRG1031. This work was supported by the Science and Engineering Research Council.

D. S. is a recipient of a Science and Engineering Rescarch Council research studentship.

\section{REFERENCES}

Gutowski, S. J. \& Rosenberg, H. (1976). Effects of dicyclohexylcarbodiimide on proton translocation coupled to fumarate reduction in anaerobically grown cells of Escherichia coli K12. Biochemical Journal 160, 813-816.

Gutowski, S. J. \& Rosenberg. H. (1977). Proton translocation coupled to electron flow from endogenous substrates to fumarate in anaerobically grown Escherichia coli K 12. Biochemical Journal I64, 265 267.

Jones, R. W Garland, P. B. (1977). Sites and specificity of the reaction of bipyridylium compounds with anaerobic respiratory enzymes of Escherichia coli. Effects of permeability barsiers imposed by the cytoplasmic membrane. Biochemical Journal 164, 199-211.

KAY, W. W. \& KORNBERG, H. L. (1971). Uptake of C 4 $^{-}$ dicarboxylic acids by Escherichia coli. European Journal of Biochemistry 18, 274-281. lemire. B. D., Robinson, J. J.. Bradley, R. D. SCraba. D. G. \& Weiner. J. H. (1983) Structure of fumarate reductase on the cytoplasmic membrane of Escherichia coli. Journal of Bacteriology IS5. 391-397.

ReID, G. A. \& INGLEDEW, W. J. (1979), Characterization and phenotypic control of the cytochrome content of Escherichia coli. Biochemical Journal 182. 465-472.

SPEnCER, M. E. \& Guest, J. R. (1973). Isolation and properties of fumarate reductase mutants of Escherichia coli. Journal of Bacteriology' 114, 563-570.

Van der Plas, J., Hellingwerf. K. J., Seljen, H. G., Guest, J. R. WeIner, J. H. \& Konings, W. N. (1983). Identification and localisation of enzymes on the fumarate reductase and nitrate respiratory systems of Escherichia coli by crossed immunoelectrophoresis. Journal of Bacteriology 153, 1027 1037. 